\title{
IMPLEMENTASI ARTIFICIAL INTELLIGENCE UNTUK DETEKSI MASKER SECARA REALTIME DENGAN TENSORFLOW DAN SSD MOBILENET BERBASIS PYTHON
}

\author{
Risnaldy Fatwa Muharram \\ Program Studi Teknik Informatika, Fakultas Teknik dan Ilmu Komputer, \\ Universitas Indraprasta PGRI \\ Jalan Raya Tengah No 80, Kelurahan Gedong, Pasar Rebo, Jakarta Timur \\ risnaldyfatwa@gmail.com
}

\begin{abstract}
Abstrak
Penyebaran kasus Covid-19 di Indonesia tidak ada habisnya. Banyak cara yang dilakukan pemerintah untuk mengurangi angka penambahan kasus infeksi setiap harinya. Tujuan penelitian ini adalah untuk membuat sebuah program yang dapat mendeteksi masker dari wajah seseorang dengan memanfaatkan model SSD Mobilenet dari Tensorflow guna mempermudah pemantauan masyarakat dalam menerapkan protokol kesehatan. Adanya program ini juga dapat membuktikan bahwa kecerdasan buatan (AI) juga memiliki peran untuk menekan penyebaran virus covid-19. Metode penelitian yang digunakan adalah Research and Development (R\&D), metode penelitian yang digunakan untuk menghasilkan produk tertentu, dan menguji efektifitas produk tersebut. Penelitian R\&D adalah suatu proses atau langkah-langkah untuk mengembangkan suatu produk baru atau menyempurnakan produk yang telah ada.
\end{abstract}

Kata Kunci : Pemograman, Python, Deteksi Objek, Covid-19

\begin{abstract}
The spread of Covid-19 cases in Indonesia is endless. The government has taken many ways to reduce the number of additional cases of infection every day. The purpose of this study is to create a program that can detect masks from a person's face by utilizing the SSD Mobilenet model from Tensorflow to facilitate community monitoring in implementing health protocols. The existence of this program can also prove that artificial intelligence (AI) also has a role to play in suppressing the spread of the COVID-19 virus. The research method used is Research and Development $(R \& D)$, research methods used to produce certain products, and test the effectiveness of these products. Research $R \& D$ is a process or steps to develop a new product or improve an existing product.
\end{abstract}

Keyword : Programming, Python, Object Detection, Covid-19

\section{PENDAHULUAN}

Dengan banyaknya kasus infeksi virus Covid-19 ini mewajibkan setiap individu untuk mematuhi protokol kesehatan. Salah satunya yaitu memakai masker dengan harapan orang-orang yang terinfeksi tetapi tidak mengalami gejala infeksi tidak akan menyebarkan virus melalui tetesan air liurnya. Sebagai Mahasiswa Universitas Indraprasta PGRI, saya pribadi berupaya membantu warga dan pemerintah khususnya untuk meredam penyebaran virus Covid-19 [1]. Dengan tersedianya teknologi yang selalu berkembang pesat dari waktu ke waktu, terutama di Indonesia yang sedang dalam Era Industri 4.0 dengan teknologi digital sebagai kuncinya. AI (Artificial Intelligence) atau bisa disebut pembelajaran kecerdasan buatan salah satu teknologi informasi yang sedang berkembang di Industri 4.0. Dan salah satu ilmu AI yang sedang berkembang adalah Machine Learning (ML) [2]. Ian Goodfellow, dkk (2016) menyebutkan di dalam bukunya "Machine learning is essentially a form of applied statistics with increased emphasis on the use of computers to statistically estimate complicated functions". Machine Learning (ML) adalah studi tentang algoritma komputer yang meningkat secara otomatis melalui pengalaman dan penggunaan data yang berguna. Perancangan dan pengembangan sebuah algoritma yang memungkinkan suatu komputer dapat mengembangkan perilaku berdasarkan data yang sudah diberikan [3]. Tensorflow adalah library open source yang dikembangkan oleh tim Google Brain untuk komputasi numerik 
dan machine learning skala besar [4]. Tensorflow menggabungkan banyak model, algoritma machine learning dan algoritma deep learning (jaringan syaraf) [5]. Tensorflow menggunakan Python untuk menyediakan API front-end untuk membangun aplikasi dengan framework, sekaligus menjalankan aplikasi tersebut dengan performa tinggi [6]. Tensorflow dapat melatih dan menjalankan jaringan syaraf tiruan untuk klasifikasi tulisan tangan, pengenalan gambar, penyematan kata, recurrent neural network, sequence-to-secuence models untuk terjemahan, pemrosesan natural language, dan simulasi berbasis PDE (Partial Differential Equation) [7]. Dengan melihat kesempatan ini, penulis berupaya untuk memanfaatkan ML untuk mencegah penyebaran virus Covid-19 dengan melihat faktor utama penekanan penularan virus yaitu menggunakan masker. Melihat latar belakang di atas maka akan dibuatkan sebuah program dengan "Impelementasi Artificial Intelligence Untuk Mendeteksi Masker Secara Realtime dengan Tensorflow dan SSD Mobilenet berbasis Python" [8]. MobileNet adalah model arsitektur Convolutional Neural Network (CNN) untuk klasifikasi gambar dan Mobile Vision. Terdapat pula model yang lainnya, tetapi yang membuat MobileNet istimewa adalah daya komputasi yang sangat kecil untuk menjalankan dan menerapkan pembelajaran (learning) [9]. Hal ini membuat MobileNet sangat cocok untuk perangkat seluler, embedded system serta computer tanpa GPU atau komputasi computer yang kurang efision dengan mengorbankan sedikit akurasi yang dihasilkan. Karena arsitektur [10]. MobileNet menggunakan lapisan atau layer konvolusi dengan tebal filter yang sesuai dengan tebal dari input citra [11]. Terdapat dua konvulsi pada MobileNet yaitu depthwise convultion dan pointwise convultion. Single Shot MultiBox Detector adalah salah satu algoritma deteksi objek yang memiliki komputasi pembelajaran dan kinerja yang baik dan sangat cocok untuk deteksi secara realtime. [12]. Menerapkan sistem Bounding Box untuk meperhitungkan lokasi objek yang terdeteksi. Medtode ini dipengaruhi oleh beberapa factor seperti epoch, jumlah batch, jumlah lapisan konvulsi, step training, dll [13].

\section{PENELITIAN RELEVAN}

Penelitian pertama (Prisky Ratna Aningtiyas, Agus Sumin dan Setia Wirawan) membahas tentang pengembangan sebuah aplikasi deteksi objek dengan menggunakan Tensorflow Object Detection API dan SSD MobileNet V2 sebagai model pra-terlatih. Aplikasi berhasil dibuat sesuai dengan harapan peneliti. Mampu mendeteksi objek seperti Kamera, Handphone, Headphone, Mouse, dan Laptop. Pengujian dilakukan dengan 50 test set dengan jumlah masing-masing objek sebanyak 10 gambar. Objek kamera mendapatkan tingkat akurasi rata-rata 99\%, Handphone, Headphone, dan Laptop sebesar 89,1\%, dan yang terakhir Mouse dengan tingkat akurasi di angka 98,8\%. Apliasi ini hanya bisa mendeteksi objek dari sebuah gambar saja. Peneliti pun berharap agar aplikasi ini dapat dikembangkan lebih jauh, dan ditambahkannya fitur-fitur seperti mendeteksi lebih dari satu objek, realtime image processing, serta dapat digunakan di berbagai macam platform [14].

Penelitian kedua (Vivian Alfionita Sutama, Suryo Adhi Wibowo, dan Rissa Rahmania) membahas tentang pengaruh step training terhadap hasil akhir dengan menggunakan metode Singles Shot Multibox Detector untuk marker dalam teknologi Augmented Reality. Pada penelitian ini, dapat disimpulkan bahwa jumlah step training mempengaruhi parameter perfomansi pada sistem deteksi objek. Hasil terbaik didapat pada step training ke 75000 dengan nilai akurasi sebesar 70,17\%, IoU sebesar 51,29\%, dan presisi sebesar 3,61. Perfomansi sistem akan semakin meningkat apabila jumlah step training bertambah karena semakin banyak jumlah step training, maka semakin banyak sistem belajar tentang data yang ada didalamnya. Sehingga, sistem akan memperbarui parameternya secara berkala dan menyebabkan loss pada sistem berkurang. Akurasi yang tinggi dan nilai presisi yang rendah dapat meningkatkan perfomansi deteksi objek sebagai marker pada teknologi AR. Hal tersebut dikarenakan tingginya akurasi memberikan deteksi secara akurat. Sedangkan, nilai presisi yang rendah yaitu mendekati 0 akan memberikan deteksi pada gerakan pointer secara mulus dan posisi yang tepat. Selain itu, SSD memiliki kecepatan deteksi yang tinggi sehingga cocok untuk deteksi secara real-time [15]. 


\section{METODE PENELITIAN}

Jenis penelitian yang digunakan adalah penelitian eksperimental yaitu dengan melakukan eksperimen terhadap variabel kontrol (input) untuk menganalisa output yang dihasilkan. Output yang dihasilkan akan dibandingkan dengan output tanpa variabel control [16]. Research and development $(R \& D)$ adalah metode penelitian yang digunakan untuk menghasilkan produk tertentu, dan menguji keefektifan produk tersebut [17]. Untuk dapat menghasilkan produk tertentu digunakan penelitian yang bersifat analisis kebutuhan dan untuk menguji keefektifan produk tersebut supaya dapat berfungsi di masyarakat luas, maka diperlukan penelitian untuk menguji produk tersebut. Jadi penelitian pengembangan bersifat longitudinal (bertahap bisa multy years). Identifikasi suatu sistem terhadap kebutuhan informasi adalah hal yang harus dilakukan, tidak hanya berdasarkan kebutuhan-kebutuhan konsumsi informasi saja, tetapi juga dilihat dari manfaat aplikasi yang sudah dibuat. Adapun tahapan-tahapan pada penelitian ini dibuat secara bertahap. Berikut adalah gambaran umum tahapan yang akan dilakukan pada penelitian ini, dapat dilihat pada gambar di bawah ini:

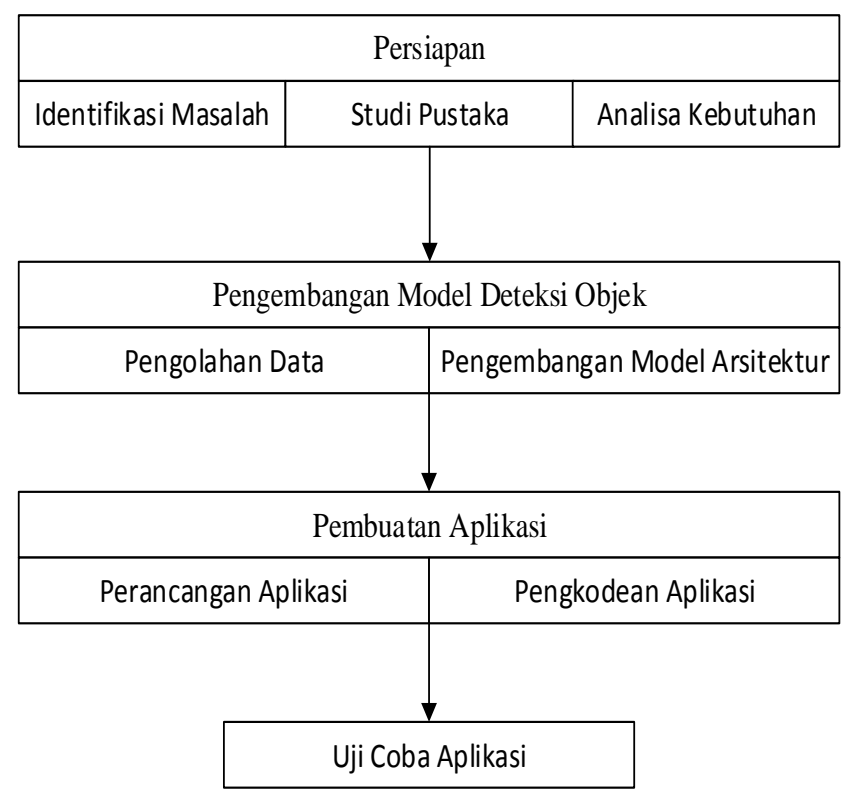

Gambar 1. Metode Penelitian

\section{HASIL DAN PEMBAHASAN}

Dari permasalahan yang sudah dibahas. Menurut penulis, mematuhi protokol kesehatan adalah upaya yang wajib kita lakukan untuk menekan angka kasus positif Covid-19. Dengan ini muncul ide untuk membuat sebuah program atau aplikasi untuk mendeteksi wajah orang yang memakai dan tidak memakai masker. Aplikasi atau program ini dapat mengenali sebuah wajah yang diambil atau direkam oleh kamera maupun perangkat yang dapat merekam sebuah kejadian. Dari sini aplikasi kemudian menampilkan sebuah informasi apakah wajah tersebut memakai masker atau tidak. Dengan begitu pemantauan terhadap masyarakat dalam mematuhi protokol kesehatan akan lebih mudah karena dengan adanya aplikasi ini meringankan tenaga kerja manusia. 


\section{Flowchart}

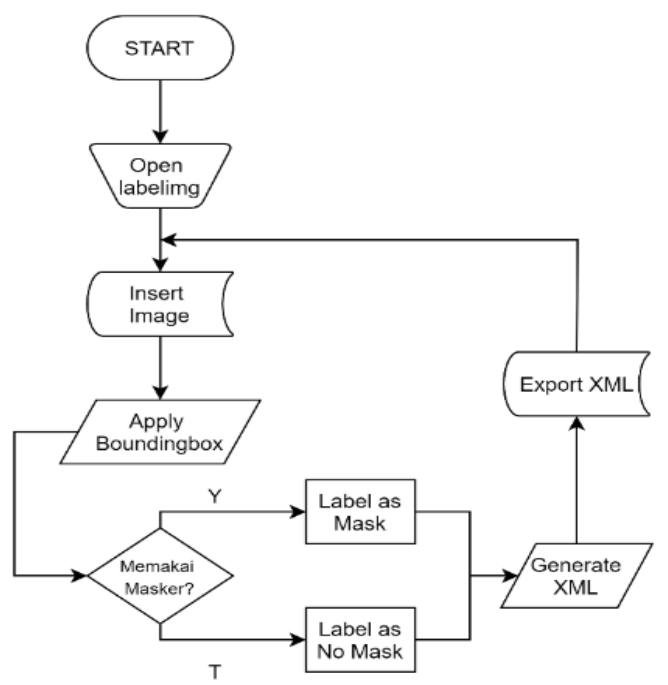

Gambar 2. Flowchart Image Labeling

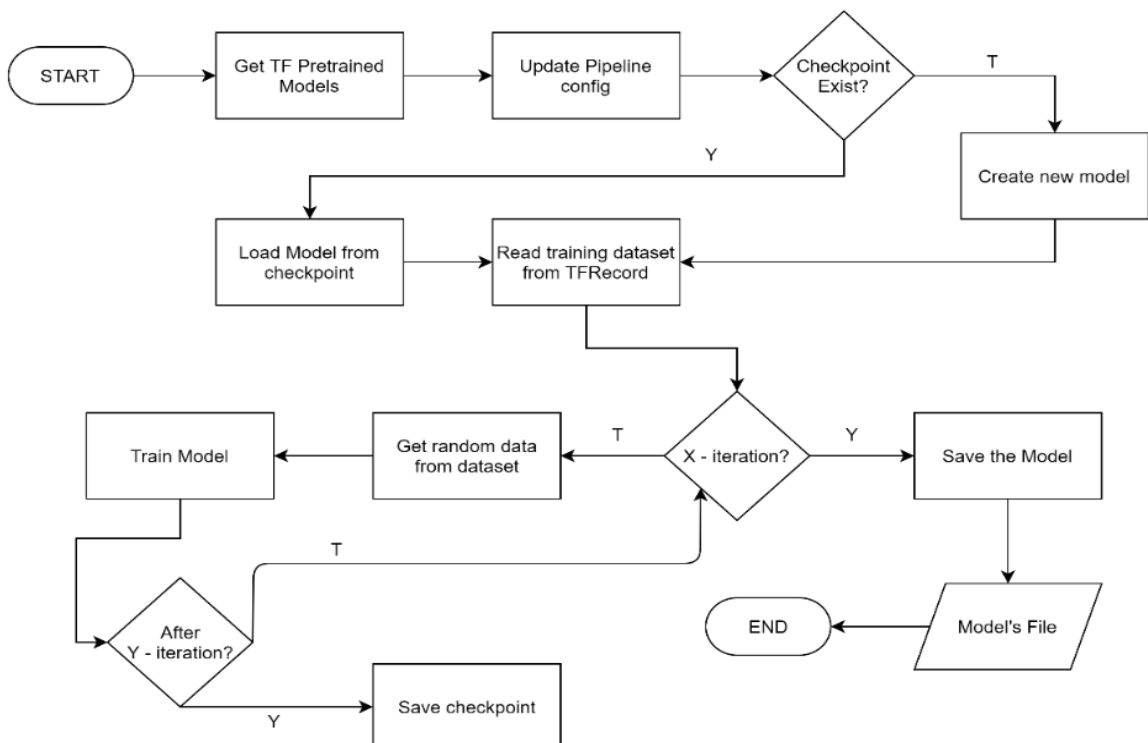

Gambar 3. Flowchart Model Training

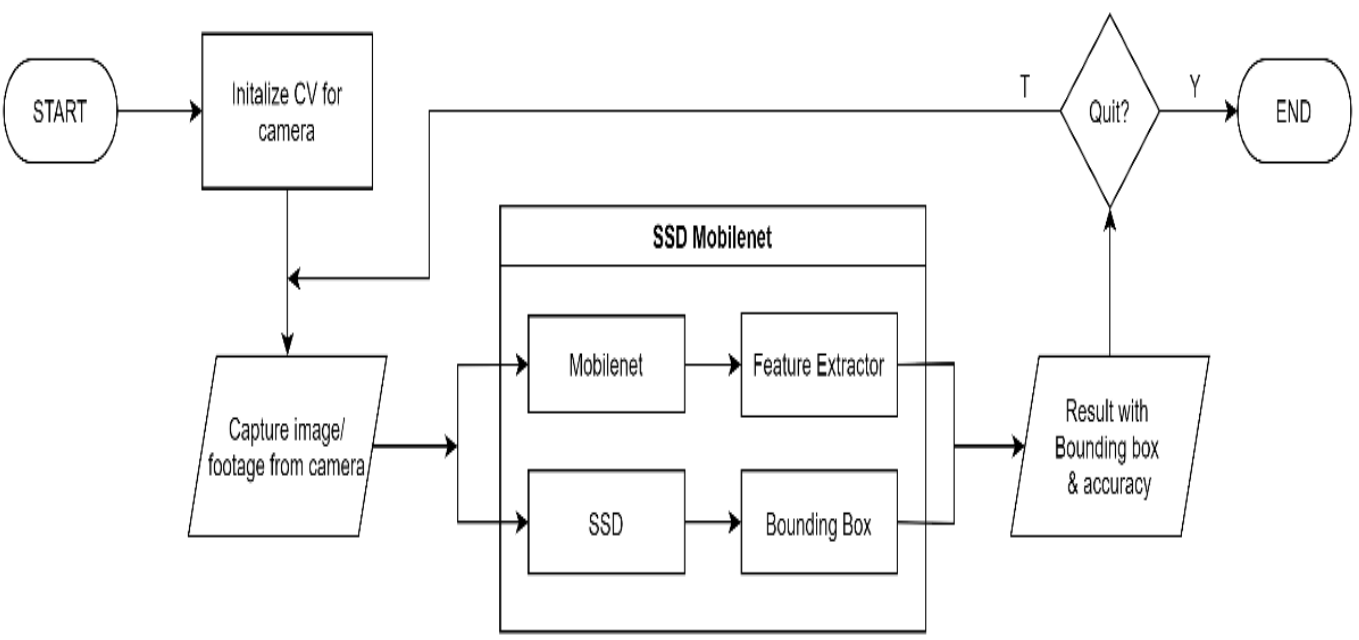

Gambar 4. Flowchart Deteksi Masker 
Uji coba program dilaksanakan dengan tujuan untuk mengetahui apakah program dapat berjalan dengan baik pada sistem operasi yang terdapat Python maupun tidak. Pengujian bermaksud untuk mengetahui perangkat lunak yang dibangun sudah sesuai dengan perancangan yang sudah dibuat dan memastikan hasil dari pelatihan model sudah sesuai harapan.

1. Dataset

Beberapa sampel dataset didapatkan dari pusat dataset Kaggle, Sebagian sampel yang lain saya ambil langsung dari webcam laptop pribadi. Total ada sekitar tiga puluh sembilan sampel gambar yang digunakan sebagai dataset.

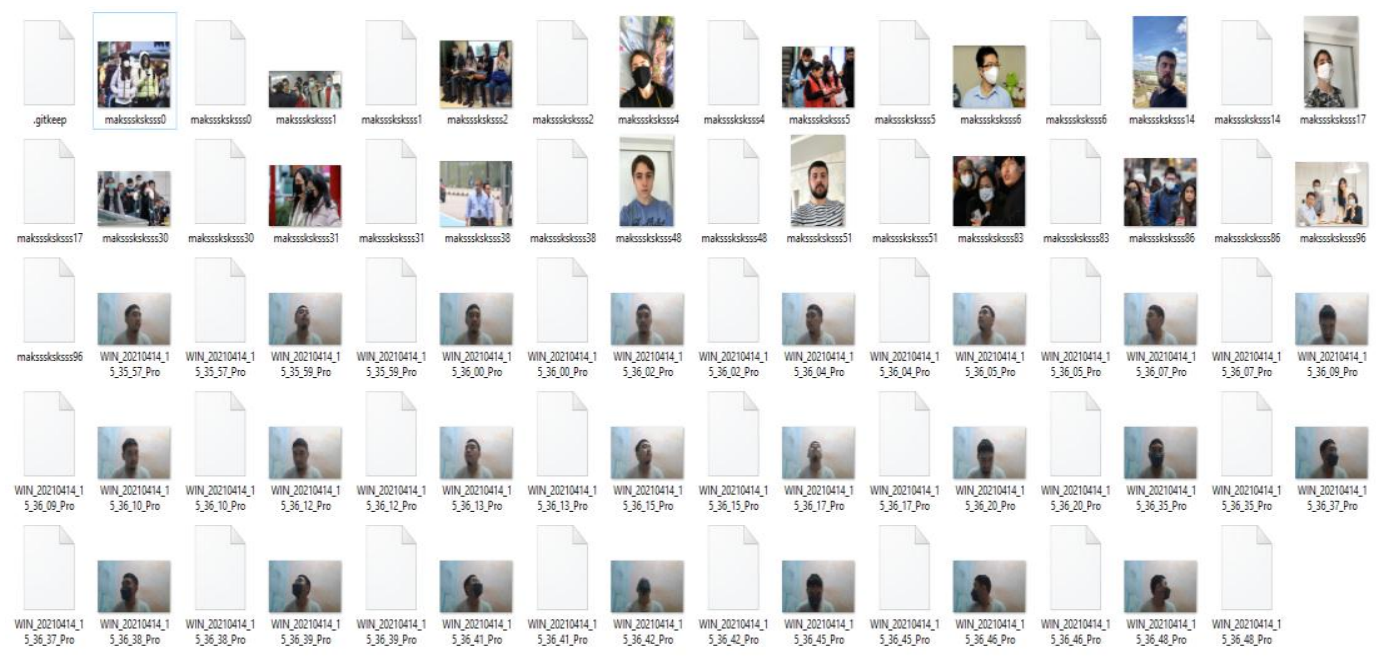

Gambar 5. Sampel dataset

2. Loss

Loss merupakan fungsi yang menentukan seberapa jauh nilai prediksi yang menyimpang dari nilai sebenarnya dalam data pelatihan. Pengubahan bobot model dapat meminimalkan nilai Loss.

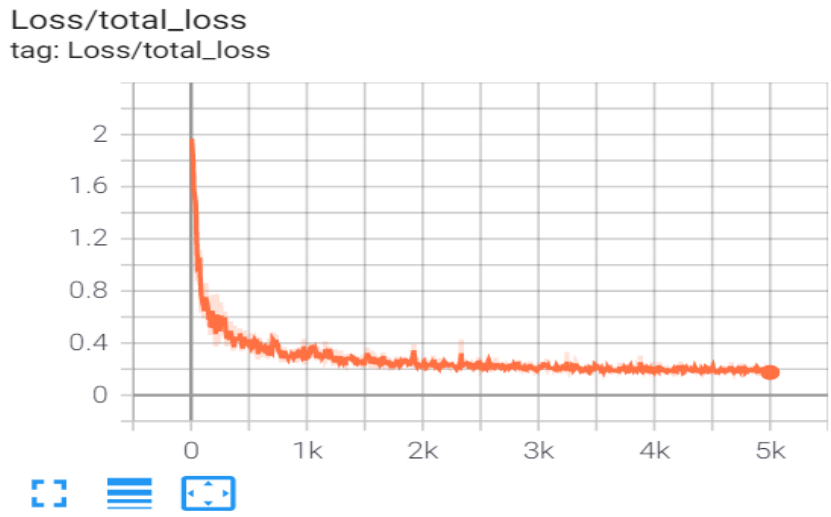

Gambar 6. Loss graph

\section{Learing Rate}

Learing rate adalah hyperparameter yang mengontrol seberapa banyak perubahan model dalam menanggapi kesalahan yang diperkirakan setiap kali bobot model diperbarui. Menentukan learning rate merupakan tantangan karena nilai yang terlalu kecil dapat mengakibatkan proses pelatihan berjalan lama, sedangkan nilai yang terlalu besar dapat mengakibatkan pembelajaran rangkaian bobot yang kurang optimal karena terlalu cepat atau proses pelatihan yang tidak stabil. 
learning_rate

tag: learning_rate

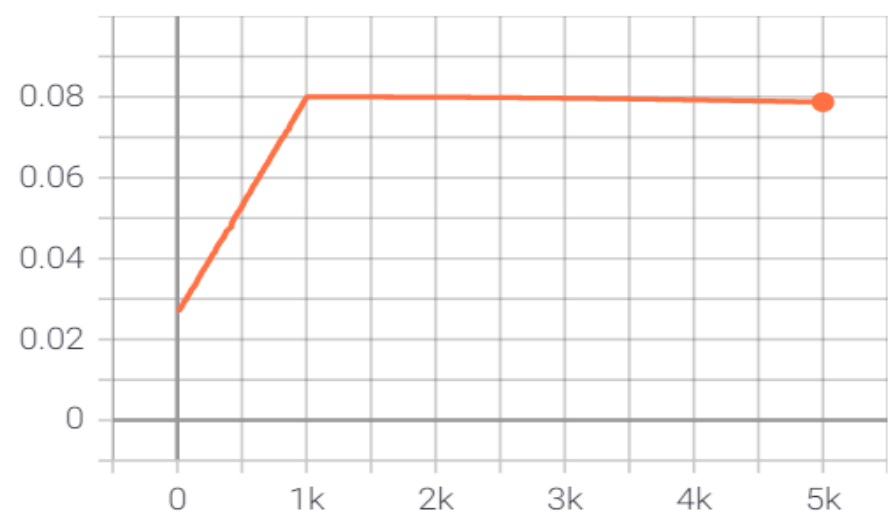

드

Gambar 6. Learning rate graph

4. Training Steps

Training steps merupakan sebuah visualisasi sebuah hasil dari proses pelatihan berlangsung. steps_per_sec

tag: steps_per_sec

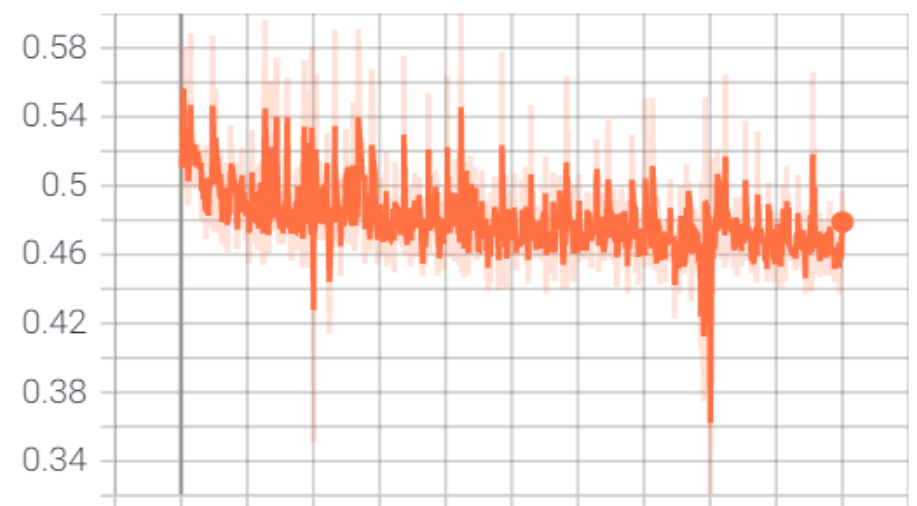

$0 \quad 500 \quad 1 \mathrm{k} 1.5 \mathrm{k} 2 \mathrm{k} 2.5 \mathrm{k} 3 \mathrm{k} 3.5 \mathrm{k} 4 \mathrm{k} 4.5 \mathrm{k} 5 \mathrm{k}$

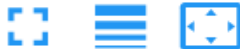

Gambar 7. Training steps graph

5. Hasil Deteksi

Model yang sudah melalui proses pelatihan akan siap digunakan untuk pendeteksian atau uji coba terhadap keberadaan masker pada seseorang yang ditandai oleh kotak berwarna beserta presentase akurasinya. 
Tabel 1. Hasil Deteksi Masker

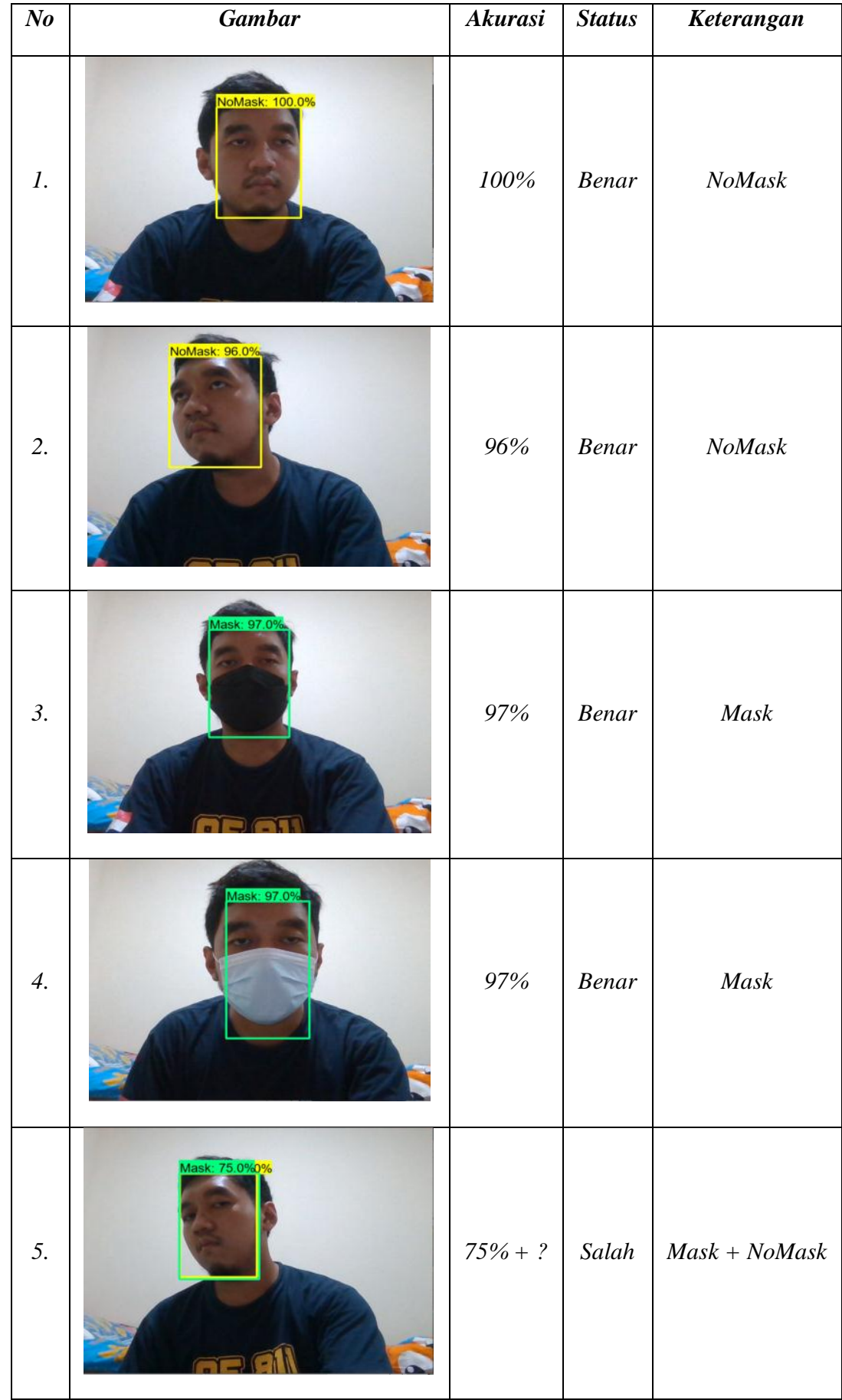

\section{SIMPULAN}

Berdasarkan uraian pembahasan analisis dan pengujian yang telah dilakukan, maka dapat diambil kesimpulan terhadap program deteksi masker dengan menggunakan tensorflow dan ssd mobilenet berbasi python :

a. Intensitas cahaya dan jarak dari kamera ke objek mempengaruhi performa serta akurasi model untuk mendeteksi objek. Akurasi tertinggi yang diperoleh mencapai 100\% dan akurasi terendah 97\% dengan asumsi model mendeteksi masker sesuai data dengan intensitas cahaya lingkungan yang sedang. Tetapi masih terdapat false detection dan pendeteksian yang overlap yang disebabkan minimnya sampel dataset dan kualitaas dataset tersebut yang belum optimal. 
b. Pemilihan jenis model untuk dilatih mempengaruhi performa pendeteksian objek secara signifikan. Terdapat model yang memiliki performa COCO mAP yang bagus, tetapi respon dalam mendeteksi objek menjadi kurang cepat. Dalam sistem ini digunakan model yang memiliki respon deteksi yang cepat, namun untuk menompang performa tersebut, nilai COCO $\mathrm{mAP}$ harus dikurangi.

c. Peran dataset dalam sangat penting dalam pengembangan model. Sistem ini masih menggunakan dataset yang repetitif dan menyebabkan model yang dilatih tidak memiliki opsi untuk mengenal variasi objek

d. Hadirnya program yang penulis buat memberikan kemudahan dalam pemantauan masyarakat yang mematuhi salah satu protokol kesehatan yaitu memakai masker.

\section{DAFTAR PUSTAKA}

[1] Ciotti, M., Ciccozzi, M., Terrinoni, A., Jiang, W. C., Wang, C. Bin, \& Bernardini, S. (2020). The COVID-19 pandemic. Critical Reviews in Clinical Laboratory Sciences, 57(6), 365-388.

[2] Alpaydin, E. (2020). Introduction to Machine Learning. MIT Press.

[3] Alpaydin, E. (2016). Machine Learning, The New AI MIT Press.

[4] Manajang, D., Dompie, S., \& Jacobus, A. (2020). Implementasi Framework Tensorflow Object Detection Dalam Mengklasifikasi Jenis Kendaraan Bermotor. Jurnal Teknik Informatika, 15(3), 171178.

[5] Wahyudi, M., Gultom, L. M., \& Solikhun, S. (2020). Jaringan Saraf Tiruan: Algoritma Prediksi dan Implementasi. Yayasan Kita Menulis.

[6] Brownlee, J. (2019). Deep Learning for Computer Vision: Image Classification, Object Detection, and Face Recognition in Python. Machine Learning Mastery.

[7] DEWI, S. R. (2018). Deep Learning Object Detection Pada Video. In Deep Learning Object Detection Pada Video Menggunakan Tensorflow Dan Convolutional Neural Network. Universitas Islam Indonesia.

[8] Sindy, F. (2019). Pendeteksian Objek Manusia Secara Realtime Dengan Metode MobileNet-SSD Menggunakan Movidius Neural Stick pada Raspberry Pi. Universitas Sumatera Utara.

[9] Chen, L.-P., Mohri, M., Rostamizadeh, A., \& Talwalkar, A. (2019). Foundations of machine learning, second edition. Statistical Papers, 60(5), 1793-1795.

[10] Devikar, P. (2016). Transfer Learning for Image Classification of Various Dog Breeds. International Journal of Advanced Research in Computer Engineering \& Technology (IJARCET, 5(12), 2707-2715.

[11] Hossain Shaikh, S., Saeed, K., \& Chaki, N. (2014). Moving Object Detection Using Background Subtraction. Springer.

[12] Solikhun, S., \& Wahyudi, M. (2020). JARINGAN SARAF TIRUAN Backpropagation Pengenalan Pola Calon Debitur. Yayasan Kita Menulis.

[13] Rismiyati. (2016). Implementasi Convolutional Neural Network Untuk Sortasi Mutu Salak Ekspor Berbasis Citra Digital. Universitas Gadjah Mada.

[14] Aningtyas, P. R., Sumin, A., \& Wirawan, S. (2020). Pembuatan Aplikasi Deteksi Objek Menggunakan TensorFlow Object Detection API dengan Memanfaatkan SSD MobileNet V2 Sebagai Model Pra - Terlatih. Jurnal Ilmiah Komputasi, 19(3), 421-430.

[15] Sutama, V. A., Wibowo, S. A., \& Rahmania, R. (2020). Investigasi Pengaruh Step Training pada Metode Single Shot Multibox Detector untuk Marker dalam Teknologi Augmented Reality. JURNAL ILMIAH FIFO, 12(1), 3-6.

[16] Scott, K. (2014). Computer Vision Metrics: Survey, Taxonomy, and Analysis. Apress.

[17] Shafira, T. (2018). IMPLEMENTASI CONVOLUTIONAL NEURAL NETWORKS UNTUK KLASIFIKASI CITRA TOMAT MENGGUNAKAN KERAS. Universitas Islam Indonesia.

[18] Szeliski, R. (2020). Computer Vision: Algorithms and Applications. Springer Science \& Business Media.

[19] Cyganek, B. (2013). Object Detection and Recognition in Digital Images: Theory and Practice. John Wiley \& Sons.

[20] Al-Azzo, F., Taqi, A. M., \& Milanova, M. (2018). Human Related-Health Actions Detection using Android Camera based on TensorFlow Object Detection API. (IJACSA) International Journal of Advanced Computer Science and Applications, 9(10), 9-23.

[21] Siahaan, V., \& Sianipar, R. H. (2021). SINYAL DAN CITRA DIGITAL dengan PYTHON GUI. BALIGE PUBLISHING. 